Mahroo MOOSAVI

The University of Sydney

Sydney, Australia

mahroo.moosavi@sydney.edu.au

\title{
BATHHOUSES AS SITES OF PROTEST: REBELLIOUS BODIES IN THE ARTS OF EARLY MODERN IRAN
}

Recommended Citation: Moosavi, Mahroo. "Bathhouses as Sites of Protest: Rebellious Bodies in the Arts of Early Modern Iran." Metacritic Journal for $\begin{array}{lllll}\text { Comparative Studies } & \text { and } & \text { Theory }\end{array}$ https://doi.org/10.24193/mjcst.2018.6.06

\begin{abstract}
Bathhouses have a strong presence in Iranian folklore and Persian literature. In parallel with literature, there are illustrations in which the topic of bathhouses is exhibited. This paper focuses on a $16^{\text {th }}$ century Persian miniature painting in which the location of a public bathhouse is used as a place of occurrence of a homosexual love story. On the one hand, bathhouses as places of "purification", and, on the other hand, corporeal bodies as agency of tactile experience create a novel dialectic between the space and its inhabitants. In an atypical study of the spatial organisation of bathhouses in the Safavid period Iran (1501-1736), the paper argues that architecture at the beginning of Iran's modern era, not only questions the normative configurations of space, but also starts to object to the solid foundations of existing religious/societal norms.
\end{abstract}

Keywords: Vuqu style of poetry, Safavid architecture, bathhouse, secondary spaces, societal norms, perversity

By the end of the fifteenth $\mathrm{AD} /$ ninth $\mathrm{AH}$ century and at the beginning of the sixteenth $\mathrm{AD} /$ tenth $\mathrm{AH}$ century, new stylistic tendencies emerged in Persian poetry. ${ }^{1}$ $B a b a^{-}$Faghañ's poetry is distinguished from the works of poets towards the final years of the fifteenth/ninth century due to the application of "vuqut experiences" and "severe sufferings of earthly love". This was innovative at the time (Fotoohi

${ }^{1}$ All dates throughout the text are given in AD first, followed by AH. Hijri (AH) calendar is the Islamic lunar calendar employing Prophet Muhammad's migration from Mecca to Medina as its base. 
Rudmajani, Sabk-e Hendi 4). The term Vuqu* as a style of poetry might be translated as "incidentalist"2 (Losensky 6). Vuqu garat (tending to the concepts that focus on the real life experiences) in the poetry of the sixteenth/tenth century was based on a simple straightforward expression of feelings of love (Fotoohi Rudmajani, Sabk-e Hendi 4).

The literary critic and scholar Mahmood Fotoohi Rudmajani (1964- ) suggests that Persian ghazal poetry, which began to focus on detailed seemingly insignificant topics in the fifteenth/ninth century, facilitated the shift from metaphysics to real physical life experiences (Fotoohi Rudmajani, Sabk-e Hendi 4).3 Fotoohi notes that expressing real love experiences and feelings, dialogues of love in a simple language, focusing on earthly romantic emotions, explaining the real deeds of lover and beloved, love of male youth (homosexual love), unpleasant rough words, betrayal, shunning, offense, threatening, and fighting the rival in love are the main characteristics and aesthetic elements of the Vuqu style (Fotoohi Rudmajani, Sabk-e Hendi 5).

The 'divinity' that was formerly presented as a fixed and universal source of love and affection loses its literary value, and the figure of the human finds itself amongst multiple narratives of love and a novel complexity with its multiple fully characterised fragments. In this paper, I will address the visceral dynamic nature of these fragments against a univocal centripetal narrative. This fragmentation, foremost, values several details embedded within a story, which used to be secondary. Safavid architecture, as a continuation of a novel approach, originated in the Timurid period (1370/771-1506/912) and similar to the literature and arts of the time, represents this agency of intermediate so-called "secondary" spaces that are interpretive and cinematic, as they reject a main architectural narrative or an ultimate destiny with any static nature. Hammam (bathhouse) architecture, as an important Safavid public architecture typology, is focused upon in this study. The twisting corridors of the hammam(s) captivate the Safavid era architects, as the dark human feelings attract the poets of the Vuqu style. Via focusing on a shift from the singular transcendental love in the previous literary and artistic tendencies to the

\footnotetext{
2 The term Vuqu' means 'to take place' in Persian.

${ }^{3}$ Ghazal is a form of Persian poetry, normally composed of 5 to 14 bayt(s) (couplets). The first mișra (half-couplet) and all second mișrat(s) of ghazal follow similar qafie (rhyme pattern). Ghazal is usually used to express love, either the divine or earthly. It was the dominant form of poetry from the $12^{\text {th }} / 6^{\text {th }}$ to $15^{\text {th }} / 9^{\text {th }}$ century in the 'Ara'qi'style and poems of poets such as Sa'dì, Hafiz and Mawlavì.
} 
multiple possible narratives of sinful human love, I suggest that architecture at the advent of Iran's modern era not only questions the normative configurations of space, but also starts to object to the solid foundations of existing religious/societal norms.

\section{The Case of the Illustration of Hammam Raftan-i Sufi (Sufi Going to the} Bath)

Hammam(s) (bathhouses) as an important part of the everyday life of Iranians have a strong presence in the body of Persian literature. Shams-ud-din Ạhmad-i Aflakì (d. 1360/761) in Manaquib-ul-'Arifin, discussing the well-known mystic, Jalal-ud-din Muhammad-i Balkhī (d. 1273/672), also known as Mawlavī or Rumi, writes that when Mawlavi was bothered by the abundance of the crowd, he intended to go to a hammam; and because the hammam was also crowded, he went to the khazine, spending his time in warm water, settling there for three days (Haqparast 181). The text sheds light on the role of hammam(s) [bathhouses] as places of itikaf, which is a recommended worship in Islam (mustahab), in which one goes to the mosque and stays there at least for three days, devoting the time to the worship of Allah. The act of itikaf in Islam is intended to take one away from worldly engagements for a certain amount of time (Nassaji Zavvare 38). This example shows the religious/Sufi religious role of the hammam(s) (bathhouses) as private, secure zones, which the worldly routine thoughts and insecurities cannot permeate, in order to prepare the mystic for a full concentration on a non-normative ritual of itikaf. Also in Shahnama, Firdawsī (d. 1020/411), the grand poet of Iran, draws parallels between hammam(s) (bathhouses) and "tall palaces": "Like bathhouses and tall palaces / like Iran that is safe from damage"4 (Haqparast 181).

This bayt [couplet] implies that both bathhouses and tall palaces bring security from threat. This cannot be valid, if bathhouses were only places to wash the body. Bathhouses had psychological ultra-physical roles in Iranian society. The Safavid period poet, Vahshì-i Bafqì (d. 1583/991), in a bayt [couplet] about gulkhan, writes about a place normally at the back of the bathhouse building, where fuel is

\footnotetext{
4 (My translation.)
}

$$
\text { جو كَمابه و كاخ هاى بلند جو ايران كه باثد بناه از كزند }
$$


heated: "I settled in the gulkhan, until I recovered / I brightened the mirror [of my spirit] by the ashes from the gulkhan"5 (Haqparast 181).

Apart from the psychological dimensions of the bathhouse that this bayt [couplet] points to, the mention of the gulkhan as a place to settle is a reference to the tradition of dervishes gathering in the gulkhan, a dirty smoky place whose environment matched their poverty, and distinguished the situation of the mystic dervishes from the normal body of society.

In parallel fashion, some painters depicted bathhouses in their illustrations of texts, and there are at least 23 paintings from the $10^{\text {th }} / 4^{\text {th }}$ to the $16^{\text {th }} / 10^{\text {th }}$ century, in which the topic of hammam is illustrated (Tehrani et al. 63). One of the most outstanding examples is a miniature painting adapted from the Haft Awrang of Nưrud-din 'Abd-ur-rahmann-i Jamì (d. 1492/898), the Well-known $15^{\text {th }} / 9^{\text {th }}$ century Iranian poet. The illustration is called 'Hammam raftan-i Sufi' [Sufi going to the Bath], and it is assumed to have been painted by Ibrahim Mìrza, a student of Kamalud-din Bihzad (d. 1535/942), the famous painter of late Timurid and early Safavid era (Haqparast 182). Ibrahìm Mìrzàs Haft Awrang is one of the most spectacular illustration works of the era (Figure 1).

5 (My translation).

ساكن كلخن شدم تأ صاف كردم سينه را دادم از خاكتر كلفن صفا آيينه را 


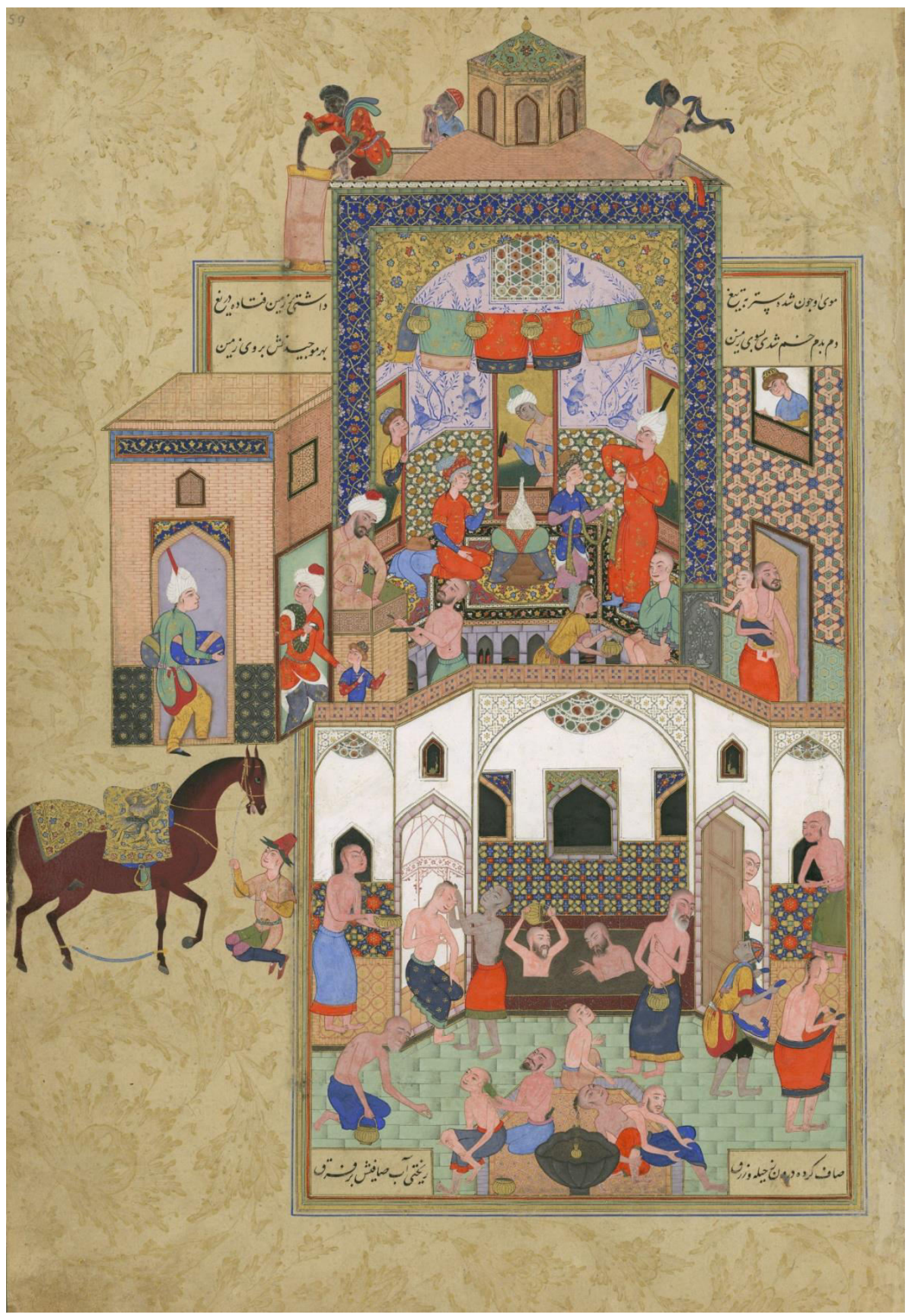

Figure 1. Miniature painting (Sufi going to the bath) attributed to Ibrahìm Mìrzà- and dated 1556-1565, Mashhad. Source: Welch, Stuart Cary. Persian Painting: Five Royal Safavid Manuscripts of the Sixteenth Century. New York: George Braziller, 1976. 
The painting consists of a diverse range of people, spaces and activities. This has led to dynamism throughout the painting, and foregrounds the prolonged narrative and the passage of time. The number of people, spaces, objects and activities is the reason why the main character and story (the Sufi and the story of him collecting the shaved hair of the young man from the floor) does not stand out, likely an intentional decision by the painter (Haqparast 182-186).

Marianna Shreve Simpson (1949- ), a scholar of early modern Islamic art and Persian illustrated manuscripts, describes the painting as masterfully structured in its organisation through the two storeys in the illustration. In the absence of "perspective" in Persian miniatures, the two-storey illustration seems an efficient technique to emphasise the sequence of activities and the line of the narrative (Haqparast 182-186). The story starts from the left side of the frame, where the presence of a horse distinguishes exterior from interior. A young man enters through a door, which is the entrance to the hammam. The bine (place of gathering, undressing and number of minor activities in the hammam, illustrated on the higher middle part of the painting) includes several characters and fine details such as the tile-work with plant and animal patterns, in which the dado and higher wall decoration are differentiated, and the source of natural light on the roof is painted in detail. On the right side of the bine, there is a door that connects the bine to the garmkhane (the place in the hammam where people would wash their bodies) where a man holding a baby is illustrated. The garmkhane is the next space in the sequence, located on the lower part of the frame. There are several undressed men in the garmkhāne, each washing. The khazine (part of the garmkhāne, in which there is a water pool, or numbers of basins), is in the higher middle part of this section where two people are bathing in the water pool. The barber's place is adjacent to the khazine, and in the lowest part of the painting on the left there is an old man with grey beard and a blue cloth covering his lower body, bending to pick up a small thing lying on the green tiles. It may be assumed that this person is the dervish of the story in the Haft Awrang of Jamì. In front of the old man, a young man wearing a grey and red cloth sits, and the barber is cutting his hair (Haqparast 182-186).

There are three bayt(s) (couplets) included as part of the painting, which are taken from the story of Murdan-i añ muraqqa'-pussh-i shūride-hal dar muhabbat-i

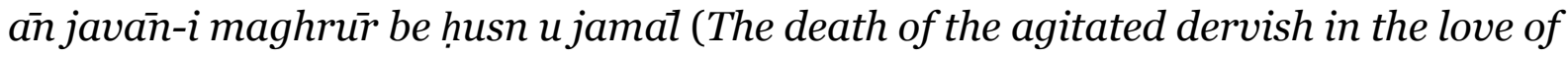


the young man arrogant of his beauty $)^{6}$ from the second book of Silsilat-uz-zahab of the Haft Awran (Modarres-e Gilani 217). A person who witnesses the love of the old dervish for a beautiful young man narrates the story. The person notices the dervish in the hammam, while he is carefully bending to pick up the shaved hair from a young man's head on the floor. The young man rejects the love and care that the dervish offers him in the hammam. Later in the story, the young man, tired of the old man's love for him, asks him to die if he is a true lover. The dervish fulfils the beloved's request and dies immediately, leaving the young man astonished; this later leads to the psychological transformation of the youth, turning him into a mystic (Modarres-e Gilani 218).

The author Jami uses the hammam as a place where a homosexual love story unfolds. While homosexual love (love of boys) is a normal phenomenon in the history of Persian literature, it is strictly prohibited in the ideology of Islam and illustrating such stories might be considered as a break with accepted religious norms under the fanatic Shi'i Safavid state. ${ }^{7}$ Another factor that makes the case of Haft Awrang exceptional, is the place where the story happens. Hammam, on the one hand, is a place of 'purification', strongly associated with taharat, and, on the other, it is a place of deviation and wrongdoing. ${ }^{8}$ The poor humiliated old dervish, who is traditionally a person rejected by social rules and norms, deeply loves the beautiful youth. This rejection by society, however, is contrary to the approach of the author, Jamì, and the

${ }^{6}$ (My translation).

$$
\begin{aligned}
& \text { موى او جون شده ستر(ده) به تيغ دانتى بر زمين فتاده دريغ }
\end{aligned}
$$

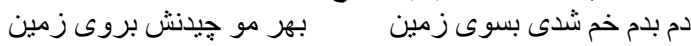

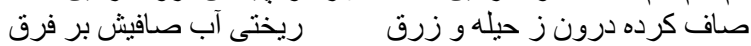

7 Fotoohi in Sad Sal Ishq-i Majażi (A hundred years of non-divine love, 2016) notes that the homosexual love has been religiously prohibited in the Islamic societies from the $8^{\text {th }} / 2^{\text {nd }}$ and $9^{\text {th }} / 3^{\text {rd }}$ centuries. However, composing poems that describe a homosexual love has been common from the same time. The poems of Sinaì, Sa'dī, Hafiz, Fakhr-ud-dīn-i 'Arāqì, Khaju-yi Kermañì and Awhad-uddin-i Kerman̄i are full of examples in which homosexual love is explicitly expressed. Awhad-ud-din-i Kermanì, clearly expresses his preference of homosexual to heterosexual love. Although Fotoohi, under the title of 'the beloved's gender' (Sad Sal 'Ishq-i Majażi: Maktab-i Vuqu' va Tarz-i Va-sukht dar Shi'r-i Farsi-i Qarn-i Dahum, 228), suggests that the religious fanaticism of the Safavid state minimised the public presence of women in the society, which might have led to the absence of heterosexual love in the poetry of the period, there are textual examples of the time that contradict this opinion. Fotoohi in page 227 of Sad Sal 'Ishq-i Majazi $i$ puts forth a text from the $5^{\text {th }}$ chapter of Risala of Ruhịi-i Anārjāìi (also known as Risala of Tabrizìān), written between 1577/985 and 1586/994, in which it is stated that Ruhị "mingles with the youth of Tabrìz", but also a list of their vices are mentioned, because "all of them (the beloved youths) were $a \bar{s} h u b$ [trouble] of a town and fitna (underlying trouble) of a time"; characteristics that made Ruhi "severely hate them and $v a$ sukhte" (The term ' $\mathrm{Va}$-sukht' is also a branch of the Vuqu' style of poetry, which emerged in the mid$16^{\text {th }} / 10^{\text {th }}$ century, and is centred around the idea of the withdrawal of the beloved) and, as a consequence, "tend to mingle with women".

8 Taharat is the religious washing ritual in Islam. 
painter of the story, Ibrahim Mirza- The painter has illustrated the old man in the garmkhane, close to the khazine, where almost everyone is undressed, a process which reaches its peak in the part of the painting where the dervish stands, implying the release from impurities and worldly affairs. The khazine is an ultimate point of purification, although this purification might happen via a so-called 'perversity'. This free representation of perversity in the artwork only becomes possible through the fragmented processional nature of the painting, which celebrates every single moment of the stories of the people within the hammam through a "non-axial" unfolding of space. There is no focal space in this miniature. Each moment is crucial, and love and perversity run along the whole space. The painting unfolds architecture, space and the story of the people in the hammam simultaneously. The asymmetrical geometry of the painting achieved through shifting the axes, the multiplicity of angles and the diversity of levels and openings turn it into an illustration of a hammam that values a narrative through movement between spaces. The interstitial spaces, including the entrance area and the space that connects the bine to the garmkhañe, and even the bine itself as a mediating space between the exterior world and the interiority of the garmkhane, value a prolonging of time and whatever perversity it constitutes.

\section{Perverted Love in Public}

The free expression of perverted love in a public place is a common phenomenon in the art and literature of the Safavid period. In the late Timurid/early Safavid society, perverted love finds its proper context in public domains. Fotoohi, in a chapter of Sad Sal 'Ishq-i Majażì (A hundred years of non-divine love, 2016), suggests that most of the romantic experiences of the Vuqu style of poetry take place in $\operatorname{bazm}(s)$ (public ceremonies) and majatis (friendly meetings). Accordingly, the terms bazm (public ceremony) and majlis (friendly meeting) are frequently used in vuqu $u^{\dagger}$ poems. The poems and illustrations of the sixteenth/tenth century early Safavid period (Shah Isma'il and Shah Tahmāsp era) include real explanations of these ceremonies (Fotoohi Rudmajani, Sad Sal Eshq-e Majazi 253). The vuqu'i poets, unlike those of the previous periods, are not interested in the 'private' moments of love (Fotoohi Rudmajani, Sad Sal Eshq-e Majazi 254). Instead, they focus on the lover looking at the beloved in a 'public' place, such as the previously mentioned ceremonies. Lisani-i Shìrazī, the sixteenth/tenth century poet of the Vuqu* style, states that it is better to 
attend a party with the beloved, instead of sitting with them in isolation (Fotoohi Rudmajani, Sad Sal Eshq-e Majazi 254). On this topic, Fotoohi notes that the lovers of the $V u q u^{*}$ style may have private meetings and conversations; however these private meetings are never explained in the Vuqu* style poems. What are counted as poetic and what fascinated the vuqui $i$ poets is the lover's feelings and the beloved's behaviour in public (Fotoohi Rudmajani, Sad Sal Eshq-e Majazi 254).

There are strong public aspects concerning the vuquit parties of the Safavid period. Unlike the Court ceremonies of the previous periods, that are reserved for high social classes, these vuqu $i$ parties welcome the middle class society as well (Fotoohi Rudmajani, Sad Sal Eshq-e Majazi 255). The poets of the Vuqu style are most interested in the detailed explanations of the critical moments when the lover faces the beloved in public. The vuqu $i$ poets use public spaces such as bazaars and feasts as the most appropriate context for their poems. There is a quality in the public exchange of feelings between two lovers, or from one lover to their beloved that fascinates the Vuqu style poets (Fotoohi Rudmajani, Sad Sal Eshq-e Majazi 255). In other words, if the lover faces their beloved in a public space in the presence of people, this would instigate certain types of behaviours in the lover and the beloved which may not happen in a private meeting. They both must be watchful of their own reactions, a mechanism that may open the horizons of interpretation. While the dialogue of love in a private space is more or less univocal, in a public space with many watching eyes, every single detailed movement or condition by the lover or the beloved may be interpreted in multiple ways. These unrevealed dark human feelings fascinated the poets of the Vuqu style, as the mysterious corridors of the hammam(s) enraptured the Safavid era architects. This resonates with the pluralism that is embedded in the spatial organisation of the Safavid period architecture.

The citizens of the Safavid Iran developed a novel ontological perspective towards social life, as the middle class entered the literary discourse, which had previously been the reserve of aristocracy. This change in societal attitudes is worth the attention of the scholars of Safavid architecture and urbanism in order to rethink the design and construction of the new city of Isfahan by Shah 'Abbas I (r. 1588/9961629/1038). This was particularly evident in the Shah's extensive construction of public buildings such as mosques, imamzäde(s), hammam(s) and grand public

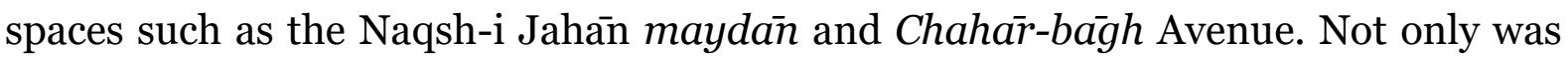


this a form of state political propaganda, but it also reflected society's demands and emerging ideological perspectives. 9

Fotoohi, on the topic of vuqui ceremonies, and after the investigation of the poems of three vuqu'i poets, declares that Mayli-i Mashhadi (d. 1576/984) has written about 'gatherings' 111 times, by using the term bazm (public ceremony) 86 times, and the term majlis (friendly gathering/meeting) 25 times. Maylì in about 51\% of the 214-page book of his poems (mostly in the form of ghazal) uses the context of public parties and gatherings. Muhtasham-i Kàshānì (d. 1588/996) has used the term bazm 147 times, and the term majlis 28 times. In the ghazal(s) of Vahshi-i Bafqì, the term bazm is used 80 times, and the term majlis'45 times. Fotoohi suggests that the high frequency of the poems of the $V u q u^{*}$ style that are set in public ceremonies and meetings sheds light on the idea that most of the emotional circumstances of the Vuqu style happened at the public parties and had been experienced by the poets of the style. Fotoohi notes that vuquit ghazal(s) are not poems of personal feelings in private; but they are the descriptions of the emotions of a poet, resulting from visiting the beloved in public (Fotoohi Rudmajani, Sad Sal Eshq-e Majazi 255-256).

In the following bayt (couplet), Khajigi 'Inayat (d. 1568/975), a poet of the $V u q u^{*}$ style, explains the popularity of his beloved in the hammam10: "He brightens the bathhouse by the beauty of his face / Every single eye [of people in the hammam] lights in watching him"11 (Fotoohi Rudmajani, Sad Sal Eshq-e Majazi 229). Riżaı-i Kàshanì (d.1587/995), another poet of the Vuqu style, describes an event in the hammam, in this bayt (couplet): "One morning, I arrived in the hammam, and saw [a beauty with] a face like a flower / What did I see? I saw a flame in the water"12 (Fotoohi Rudmajani, Sad Sal Eshq-e Majazi 229). The Vuqu style poet, Fahmi-i Astarabäì (d. after 1541/947), dedicates three intense bayt(s) (couplets) to the beauty of the face and body of his beloved, suggesting that readers should watch the fine movements of his body moving in the hammam:

\footnotetext{
9 Imaimzade is a term that refers to an edifice built on the grave of the descendants of the twelve Imams of Shi'a. In its accurate use, Imaimza'de was the Imam's descendant.

${ }_{10}$ Although Persian pronouns are gender-less, since the stories happen in public bathhouses with separate spaces allocated to male and female use, it is obvious that the male poets of the following couplets refer to male beloveds in their poems.
}

${ }_{11}$ (My translation).

12 (My translation).

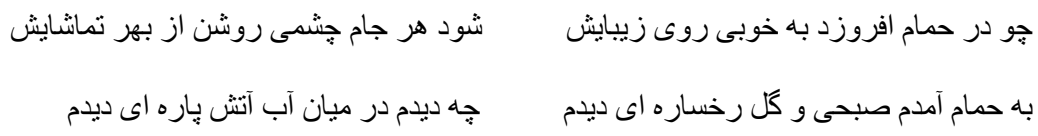


If he goes to the hammam's entrance, follow him / Watch him taking off his clothes. If you can stand it [his beauty], go to the hammam / Watch his bright face and his tender fresh body.

If he decides to leave [the hammam], [so] he stands up / Watch his body while swaggering $^{13}$ (Fotoohi Rudmajani, Sad Sal Eshq-e Majazi 429).

The crucial role that the notion of 'publicness' plays in the literature of the early Safavid period may resonate with the idea of 'prolonging of duration' that reaches its peak in the public architecture of the time of Shah 'Abbas I. In other words, the oddity of the narrative of the pervert love of the vuquit poems arises from its 'publicness'. This public context creates multiple dramatic 'moments,' each of which matters. The mechanisms by which the architecture of Safavid hammam(s) as products of the unification of these multiple "spatial moments" unfold through the movement between so-called "secondary sub-spaces", will be studied in the following section.

\section{Hammam Typology}

Hammam(s) (bathhouses) are one of the most important urban public building typologies of the Safavid era, which have enjoyed little architectural scholarly attention, according to Sussan Babaie (1954- ) and the other researchers on this topic (Babaie 195; Afrough 94-95). The fact that there are few preserved examples of Safavid hammam(s) in Iran at the present time is one of the reasons for the lack of deep investigation. Hammam, after mosque and madrasa (religious school), is amongst the most important public building typologies in the Safavid period (Poursha'banian 115). The building of public hammam(s), especially flourished in the Safavid era and in the time of Shah 'Abbās I, due to his interest in constructing public amenities built by awqaf (charitable foundations) (Floor and Kleiss). Hammam as "iconic of royal privilege in patronage" is an ever-present typology in Islamic cities and is tightly integrated in the urban fabric (Babaie 195).

13 (My translation).

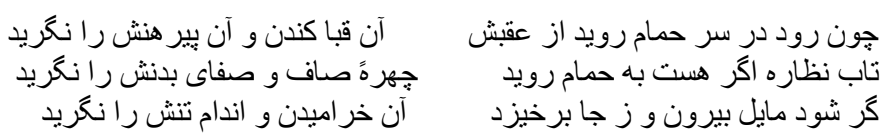


Additional to the urban-politics of hammam in Islamic lands in general, and areas under the control of Safavids in particular, the hammam in the Islamic teachings is associated with the acts of "purification", which is both hygienic and religious (Babaie 195). According to the "Bathhouses" entry by Floor and Kleiss in Encyclopaedia Iranica, the history of the hammam goes back to the pre-Islamic period in Iranian culture, when their numbers were limited as a result of the Zoroastrian religious belief about water as a 'holy' substance. It was only in the postIslam era that the ritual purity, or what in religious terms is called taharat, encouraged the construction of hammam(s) in the cities and villages, and so the concept of hammam is frequently mentioned in texts after the ninth/third century onwards (Floor and Kleiss). There are two forms of ritual purity (țaharat) in Islam: ghusl, a specific ritual for washing the whole body; and vużu, a ritual for washing parts of the body that must be performed before the namaz̄ [prayer] (Floor and Kleiss). Hammam(s) were also used for medical purposes, and, more importantly, were the social forums in which the news was exchanged and ceremonial activities were held. Hammam(s) were important social hubs, in which many interactions took place. As a result, they have been discussed in the literature, including in some parts of outstanding books such as Qabus̄nama (ca. 1082/475) which, in a section, offers advice on "proper behaviour in a bath" (Floor and Kleiss). Bathing was an essential part of the life of Persian women, who would spend many hours per week in hammam(s). Middle class society tended to hold ceremonies and parties in the hammam, and the process of washing was a collective action in which people would help each other to wash their hair and body (Floor and Kleiss). In fact, hammam(s) were not only places for washing the body, but more importantly places for social networking, in which ceremonies such as the 'hammam-i zaỹimañ' (the maternity bath), marriage ceremonies like hana-bandañ, bathing prior to the feasts, and the mourning taharat(s) were held (Haqparast 174-175). The central role of the hammam in societal life is reflected in much of the folk literature, including proverbs and superstitions. For example, some folk beliefs associate supernatural creatures called 'jinn' with hammam(s) ${ }^{14}$.

14 According to the Qur'an, jinn is a creature, in many senses and religious responsibilities, similar to the human, but is not visible to the humans. 


\section{The Architectural Layout of Hammam}

The architectural layout of a traditional hammam was complex, sometimes consisting of two or more smaller hammam(s) for male and female use, which were combined in a single building. Each hammam comprised three main spaces (Figure 2):

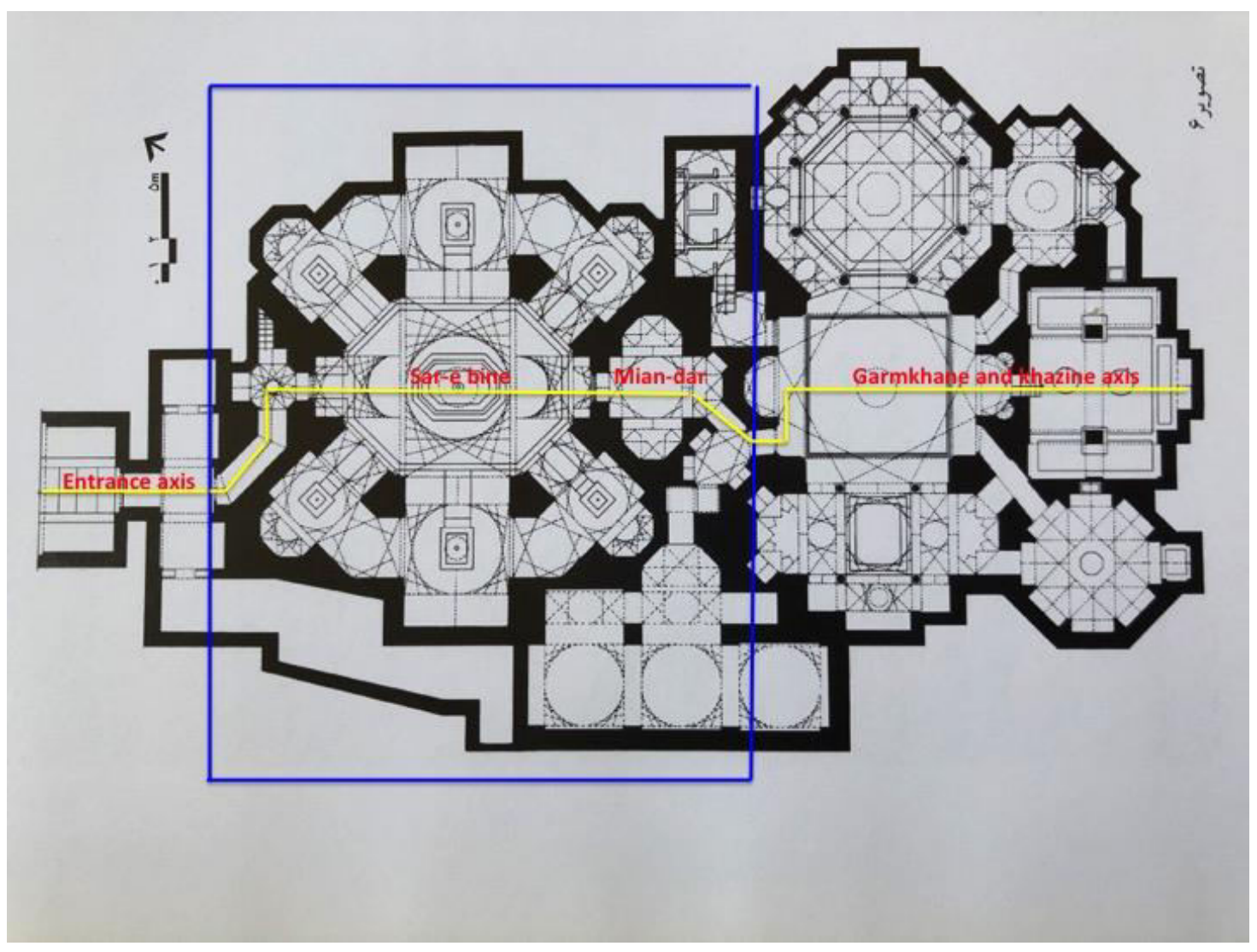

Figure 2. Ganj 'Ali Khān hammam (bathhouse), 1613, Kerman, Plan, showing the main elements of hammam, axial shift from the entrance to garmkhane, and the mediating role of sar-i bine. Diagram adapted from: Navaii, Kambiz, and Kambiz Haji Qasemi. Khehst va Khial: Sharh-e Me'mari-e Eslami-e Iran. 1st ed. Tehran: Soroush, 2011.

1) The Sar-i bine: A space for undressing (or dressing) prior to entering (or exiting) the bath (Haqparast 176-177). It was placed after an entrance space, and was usually a large octagonal vaulted room, decorated in tile-work with floral/animal patterns (Floor and Kleiss). The space under the dome and auxiliary vaults could be decorated in fine plaster $k a \bar{r}$-band $i$ decoration. Natural lighting 
would intensify the decorative elements of the space (Haqparast 178).15 Rows of benches were aligned around the space for functional and relaxation purposes. The middle space was used for the main activities. After undressing in the sar-i bine, the user would wear a cloth, called "lung", which would cover the lower body. In the sar-i bine, tea and coffee was served, and people would sometimes smoke, as they chatted in groups (Floor and Kleiss). The mild temperature of the sar-i bine prepared the body to transition from the outside to the hot washing space (garmkhā̄e) in a healthy way (or vice versa) (Haqparast 176-177) (Figure 3).

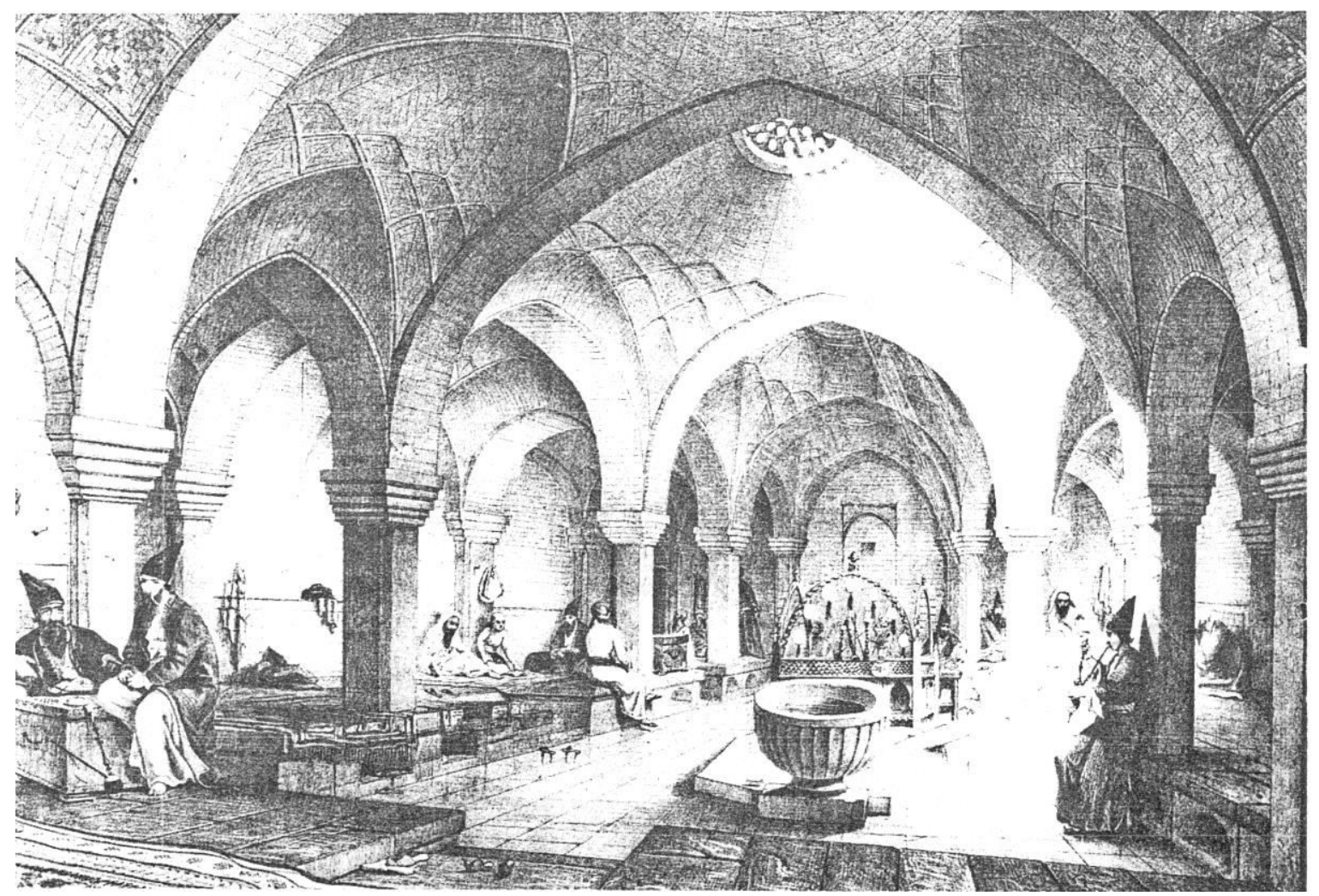

Figure 3. Drawing by Eugene Flandin and dated 1840-1842 of Khusraw A'qa hammam (bathhouse), 1698, Isfahan, Sar-i bine space. Source: Ayatollahzade Shirazi, Bagher. "Takhrib-e Asar-e Tarikhi-e Hammam-e Khosro Agha." Asar, no. 25 (1995): 2-27.

2) The Mian-dar: A mediating space between the sar-i bine and the next space (garmkhañe). Miān-dar could take the form of a twisting corridor to facilitate a smooth transition in temperature from one space to the other (Haqparast 176-177).

${ }^{15} K a \bar{r}$-bandi: A decorative technique of creating the transitional part between the walls of the room and the dome, which is made up of structural crossing arches. 
The miañ-dar might accommodate some step-like benches for sitting and doing personal activities like shaving. The bathrooms could be reached through a route that diverged from the miañ-dar.

3) The Garmkhane: A steam room, often smaller than sar-i bine. The garmkhañe was the washing space, usually a rectangular, square or octagonal shape, divided by pillars into many sub spaces. These sub-spaces provided the user with bathing facilities. The walls and ceilings could be decorated with different techniques. The middle of the garmkhane generally had a vaulted ceiling, and natural lighting was provided for the room through skylights (Haqparast 178). The garmkhañe included one or more large water basins, called a khazine, situated on tuin [the source of heating] (Floor and Kleiss). Khazine was used for the final washing and taharat, after the whole process of bathing was finished. It could be located on and at the end of the same axis as the entrance to the garmkhane (Haqparast 178).

The sequential movement from the entrance to the garmkhañe, and particularly to the khazine, where the final act of "purification" occurred, consisted, in many cases, of four main and two interstitial spaces: 1) The entrance, 2) sar-i bine, 3) garmkhañe, and 4) khazine, as the central spaces; and 1) Connecting spaces between the entrance and sar-i bine, and 2) Connecting space between the sar-i bine and garmkhañe (called mian-dar, the same as the entrance corridor) as the interstitial elements. The interstitial elements are important parts of this study, as they are not simple connectors, but have distinguishing characteristics. It is to be noted that the sar-i bine is normally larger than the garmkhane and is the most elegant room in the hammam in terms of the fine ornamentation and elaboration of decorative elements. However, the act of "washing" as the main function of the hammam typology takes place in the garmkhañe and khazine, which in a sense defines the sar-i bine as a space to pass in order to reach the defined purpose of using the hammam in the garmkhañe. In another spatial/functional interpretation, the sar-i bine is also a connector interstitial space that can thematically be combined with the mian-dar/s. As a result, the building may be redefined through three essential realms: 1) Entrance 2) Sar-i bine as a connector (See Figure 2, blue lines), and 3) garmkhañe. The entrance and the garmkhane in most of the cases are not aligned on the same axis and the sar-i bine acts as a mediator, which facilitates a smooth transition from the entrance to the garmkhañe. 


\section{Indiscernibility through Mediating Spaces}

The idea that interstitial spaces are not simple connectors, but pivotal functions, relates not only to morphological aspects, but is evident in the psychological dimensions of architecture as well. This has also been reflected in the art and folklore of the time. In the case of the hammam, the sar-i bine is an important place for social interaction and for the exchange of news and information. The "secondary" place of undressing to enter the garmkhañe, receives a "primary" function, in which people sit on the designed benches around the space, relax and talk (Floor and Kleiss). The sar-i bine, more than being a physical mediator of axial differences and a device to make possible the amalgamation of non-compatible main volumes in a building, is a mechanism of neutralisation of the polarity and binary nature of the outside society. To enter the garmkhane, everyone must undress; the act that purifies the body of the normative definitions of societal class. The 'purification' that happens in the hammam is not only limited to the literal physical "ablution", but extends to the erasure of any unwanted additional codes attached to the human. People enter the hammam with their dress codes, each referring to a certain class of society; however, the process of passing the mediating sar-i bine, revives the balance and the neutrality of space, freeing the people who enter the washing room from binary codes.

The history of hammam in the Islamic/Iranian culture is also marked by dramatic moments, such as the cases of murder in the hammam, which may highlight a perversion or deviation from normative behaviours in this context. One of the most dramatic incidences in a hammam was the case of the murder of MirzaMuhammad Taqī Khān-i Farahan̄ì, known as Amìr Kabìr (d. 1852/1268), the chief minister to Nașir-ad-din Shah Qajar of Iran. Amìr Kabir was murdered in the khazine of the hammam of Fin in Kāshan, on the command of the Shah. ${ }^{16}$

The anonymity within Safavid public buildings resonates with the rejection by individuals, as social units, the state of being constantly under surveillance. The prioritising of individuals over specific groups introduces the possibility of the free expression of abnormal or perverted behaviour, either directly, in the form of poetry

\footnotetext{
${ }^{16}$ The association of bathhouse and murder or, in general, any deviation from normative behaviours has extended to the contemporary art of Iran. In the important 1969 movie Qayșar, by the well-known director Mas'ud Kìmiài, Qayșar, the main character, takes revenge for the murder of his sister and brother by killing the Abmangul brothers, one in a slaughterhouse, and the other in a public bathhouse. The scenes of the stabbing in the bathhouse were shot in the Navvab hammam in the 'Udlajān neighbourhood in Tehran.
} 
(the generation of the Vuqu style in the $16^{\text {th }} / 10^{\text {th }}$ century) and painting (such as 'Sufi going to the bath'), or indirectly, through other mediums, such as architecture.

Generally, architecture is tightly interlinked with social divisions, ranks and classifications. It is associated with defined "ab-normalities", physical or psychological, which results from institutionalising and measuring the units of society through the mechanisms of power. Michel Foucault (d. 1984), in Discipline and Punish (1975), notes:

The existence of a whole set of techniques and institutions for measuring, supervising and correcting the abnormal brings into play the disciplinary mechanisms (...). All the mechanisms of power, which, even today, are disposed around the abnormal individual, to brand him and to alter him, are composed of those two forms from which they distantly derive (Foucault 199-200).

In the case of hammam, however, contrary to many other typologies such as prisons, correctional centres, institutional buildings, and hospitals, the 'branding' that simplifies the acts of measurement, supervision and correction, temporarily disappears. This occurs through a functional un-labelling process in the act of undressing prior to the washing of the body. There is, however, more to this process of un-labelling and escaping the normative system. According to Foucault "visibility is a trap" (Foucault 200). In traditional axial architecture, the visibility resulting from the singular main axis, symmetry and repetition, minimises the possibility of behavioural deviations. Everything is visible by everyone, and this produces a process of self-discipline. While the spatial organisation of a traditional axial public building automatically leads to the production of a disciplined society, the architectural form of the mediating space of a Safavid hammam, including the shifting axes and multiple angular turns, helps to reduce visibility in the space.

\section{Closing}

Safavid hammam(s) are rare in typologies of Persian architecture, in that they function to neutralise societal polarities through the use of mediating spaces. By using connector elements to shift the axes and disturb the symmetry, architecture begins to play the novel role of reforming spatial and religious/societal stereotypes. Therefore, the mediating spaces, as the last connections to 'normative exteriority', 
must be considered more than simple 'secondary' elements. The psychological process that takes place in these spaces seems to have been attractive to the Safavids and their architects, either consciously or unconsciously. Although this unification of the different classes of the society through the hammam is not limited to the architecture of the Safavid period, and is essentially based on the very idea of hammam(s) as places of 'purification' and 'release', in the Safavid public buildings (as a continuation of the predecessor Timurid approach), this mechanism of decategorisation occurs through a more gradual process. This gradual process is a consequence of the focus on the design of the mediating spaces, which deeply engages the visitors' psychological/experiential spatial presence and fully prepares them to enter the main space.

In hammam architecture, benches were often provided for visitors to sit and relax in privacy prior to entering the washing space at the mian-dar, where the sar-i bine (the undressing area) joins the garmkhañe. A long corridor would lead from that point to the bathrooms and to other rooms that accommodated activities such as colouring the hair and hijamat (wet cupping) (Tehrani et al. 66) ${ }^{17}$. These twists and turns, with their minimum axial visibility, create new opportunities for deviation and perversion. The irregularity and unpredictability of these fragmentary secondary spaces intensifies the non-visibility and leads to an indiscernibility. This atmospheric indiscernibility reminds the individuals of their human existence. As the painting of 'Sufi going to the bath' shows how the mediating spaces might prepare one for a different type of relationship or love, so the secondary spaces of a Safavid hammam are places of thought that drop one, that allow something to happen. The term vuqu, which is used for the style of Persian poetry in the $16^{\text {th }} / 10^{\text {th }}$ century, is defined in the Lughat-name-yi Dehkhoda (Dehkhoda Dictionary) as 'to drop' ("Vuqu'"). This 'dropping,' which is also present in the infinitive 'ittifā ufta'dan' (to happen) in Persian, implies a 'place' to contextualise the dropped happening. There should be a place for romance to occur. Unexpectedly, this may be a public place like a hammam. The traditional neutral corridor, which would normally emphasise the final destination, shifts to a dynamic corridor that brings more architectural features to the user's attention. The pluralism that results when balance and symmetry are overshadowed by the presence of an irregular mediating space prepares the user to

${ }^{17}$ Hijamat is an old traditional Chinese/Greek/Middle Eastern therapeutic medication through which an amount of blood is drawn from minor scratches on the skin, using vacuum, and is believed to purify the body of diseases. 
think outside of symmetry and norms and to feel unbalanced and free. This progressive approach is not only limited to the architecture of the Safavid period, which began to emerge in the preceding Timurid era in the $14^{\text {th }} / 8^{\text {th }}$ and $15^{\text {th }} / 9^{\text {th }}$ centuries, but is also evident in the literature, especially in the poetry of the late Timurids and Safavids and in the emergence of the Vuqu' style after the centurieslong dominance of the meta-narrative 'Araiq $i$ 'style.

Hammam architecture, as an important Safavid typology, similar to many other societal milieus at the beginning of Iran's modern era, starts to object to the solid foundations of existing religious/societal norms and shifts from its traditionally defined univocal function to a groundbreaking hermeneutical pluralism.

\section{References}

Afrough, Mohammad. "Vijegi-ha-ye Hammam-ha-ye Iran dar Dowre-ye Safavi." Ketab-e Mah-e Honar, no. 130, 2009: 94-101.

Ayatollahzade Shirazi, Bagher. "Takhrib-e Asar-e Tarikhi-e Hammam-e Khosro Agha." Asar, no. 25, 1995: 2-27.

Babaie, Sussan. "Sacred Sites of Kingship: The Maydan and Mapping the SpatialSpiritual Vision of the Empire in Safavid Iran." Persian Kingship and Architecture: Strategies of Power in Iran from the Achaemenids to the Pahlavis. Edited by Sussan Babaie, and Talinn Grigor. New York: I.B. Tauris \& Co Ltd., 2015: 175-218.

Floor, W., and W. Kleiss. "Bathhouses." Encyclopaedia Iranica. Web. 19 July 2017. http://www.iranicaonline.org/articles/bathhouses

Fotoohi Rudmajani, Mahmood. "Sabk-e Hendi." Danesh-name-ye Zaban va Adab-e

Farsi dar Shebhe-Qarre. Edited by Mohammad Reza Nasiri. Tehran: Farhangestan-e Zaban va Adab-e Farsi, 2013: 2-29.

Fotoohi Rudmajani, Mahmood. Sad Sal Eshq-e Majazi: Maktab-e Voqu'va Tarz-e Va-Sukht dar She'r-e Farsi-e Qarn-e Dahom. 1st ed. Tehran: Sokhan, 2016.

Foucault, Michel. Discipline and Punish. Translated by Alan Sheridan. New York:

Vintage Books, 1995.

Haqparast, Maryam. "Sufi dar Garmabe." Faslname-ye Honar, no. 79, 2009: 174192.

Losensky, Paul E. Welcoming Fighañi: Imitation and Poetic Individuality in the Safavid-Mughal Ghazal. Costa Mesa, California: Mazda Publishers, 1998. 
Modarres-e Gilani, Morteza, ed. Masnavi-e Haft Owrang. Nur-ud-din Abd-urrahman-e Jami. Tehran, Mahtab, 2010.

Nassaji Zavvare, Esmaeil. “E'tekaf.” Pasdar-e Islam, no. 249, 2002: 36-40.

Navaii, Kambiz, and Kambiz Haji Qasemi. Khehst va Khial: Sharh-e Me'mari-e Eslami-e Iran. 1st ed. Tehran: Soroush, 2011.

Pour-sha'banian, Zahra. "Hammam-e Safavi-e Niloofar." Vaqf-e Miras-e Javidan, no. 82, 2013: 115-124.

Welch, Stuart Cary. Persian Painting: Five Royal Safavid Manuscripts of the Sixteenth Century. New York: George Braziller, 1976.

Tehrani, Farhad, Maede Pour-fathollah, and Zahra Qasemi. "Barrasi-e Tatbiqi-e Nahve-ye Afarinesh-e Faza-ha-ye Me'mari dar Asar-e Negargari-e Hammam”, Faslname-ye Elmi Pajouheshi-e Negare, no. 26, 2013: 60-72.

"Vuqu'." Dehkhoda Dictionary. Web. 24 July 2017.

http://www.vajehyab.com/dehkhoda/وقوع

\section{Further English Sources}

Arberry, A. J. Classical Persian Literature. London: Allen \& Unwin, 1958.

Babaie, Sussan. Isfahan and its Palaces: Statecraft, Shiism and the Architecture of Conviviality in Early Modern Iran. Edinburgh, Edinburgh University Press, 2008.

Binyon, Laurence, J. V. Wilkinson, and Basil Gray. Persian Miniature Painting. New York, Dover Publications, 1971.

Gray, Basil. Persian Painting. New York, Rizzoli, 1977.

Rypka, Jan. "Persian Literature to the Beginning of the $20^{\text {th }}$ Century." History of Iranian Literature. Edited by Karl Jahn. Dordrecht. D. Reidel, 1968: 69-418.

Yarshater, Ehsan. "Persian Poetry in the Timurid and Safavid Periods." The Cambridge History of Iran, 965-994. Edited by Peter Jackson and Laurence Lockhart. Cambridge, Cambridge University Press, 1986. 